\title{
Transactions
}

Cite this: Dalton Trans., 2011, 40, 4505

wWW.rsc.org/dalton

PAPER

\section{Oxidative properties of iodine-adducts of propylthiouracil and methimazole: Direct synthesis of mercury(II) complexes from the reaction with liquid mercury ${ }_{\dagger}^{\dagger}$}

\author{
Francesco Isaia, ${ }^{* a}$ M. Carla Aragoni, ${ }^{a}$ Massimiliano Arca, ${ }^{a}$ Claudia Caltagirone, ${ }^{a}$ Carlo Castellano, ${ }^{b}$ \\ Francesco Demartin, ${ }^{b}$ Alessandra Garau, ${ }^{a}$ Vito Lippolis ${ }^{a}$ and Anna Pintus ${ }^{a}$
}

Received 18th October 2010, Accepted 2nd February 2011

DOI: 10.1039/c0dt01409e

The $\mathrm{I}_{2}$-adducts of drugs propylthiouracil (PTU) and methimazole (MeImSH) oxidize liquid mercury in dichloromethane to separate in good yield the neutral complexes $\left[\mathrm{HgI}_{2}(\mathrm{PTU})_{2} \cdot \mathrm{MeOH}\right](\mathbf{1})$,

$\left[\mathrm{HgI}_{2}(\mathrm{PTU})_{2} \cdot \mathrm{HgI}_{2}\right](\mathbf{2})$, and $\left[\mathrm{Hg}_{2} \mathrm{I}_{4}(\mathrm{MeImSH})_{2}\right](3)$. The single crystal X-ray diffraction analysis of 1-2 shows that the $\mathrm{Hg}$ (II) center is coordinated by two sulfur atoms and by two iodine atoms in a tetrahedral geometry. In complex 2 almost linear molecules of $\mathrm{HgI}_{2}$ result encapsulated in the crystal packing enfolded by the hydrophobic propyl appendages of coordinated units of PTU. X-ray analysis of complex 3 shows the presence of dimeric $\left[\mathrm{Hg}_{2} \mathrm{I}_{4}(\mathrm{MeImSH})_{2}\right]$ molecules to form $\mathrm{Hg}_{2} \mathrm{~S}_{2} \mathrm{I}_{4}$ cores. The intraand intermolecular hydrogen bonds concerning PTU and MeImSH have been evaluated. The oxidation of $\mathrm{Hg}(0)$ to $\mathrm{Hg}(\mathrm{II})$ requires a two-electron transfer process accomplished by an oxidative addition from the "activated" iodine moiety. The oxidizing and complexing properties of PTU- $\mathrm{I}_{2}$ and MeImSH-I have been interpreted considering the $S$-donor to $\mathrm{I}_{2}$ interaction that leads to a charge separation between the sulfur-bound iodine atom S-I and the terminal I atom. Compounds 1, 2, and $\mathbf{3}$ react with tetraethylammonium iodide to separate the compound $\left(\mathrm{Et}_{4} \mathrm{~N}\right)_{2}\left[\mathrm{HgI}_{4}\right]$ with the release of free PTU and $\mathrm{MeImSH}$, respectively. The reported dissolution technique could be applied to the recovery of mercury from waste electrical and electronic equipment (WEEE) scrap, the nature of complexes 1-3 makes it possible the easy separation of the mercury as tetraiodomercurate anion and the recycling of the donors.

\section{Introduction}

Among all heavy metals, mercury is certainly the most toxic and causes many environmental problems as well as adverse health effects upon exposure to one of the three forms of mercury: elemental, inorganic, organic. ${ }^{1-3}$ With this in consideration, the development of efficient processes for the recovery of $\mathrm{Hg}(0)$ from contaminated soils and material wastes is of crucial importance. In recent years it has been shown that a great number of zerovalent metals, including gold and palladium, can be easily oxidized in a non-aqueous media by the $\mathrm{I}_{2}$-adducts of sulfurcontaining donors ${ }^{4}$ with formation of neutral or ionic metalcomplexes featuring a variety of geometries and oxidation states. ${ }^{5}$ Good results have also been reported in the oxidation of liquid mercury employing the $\mathrm{I}_{2}$-adduct of chelating $S, S^{\prime}$-donors tetraphenyldithioimidodiphosphinic $\operatorname{acid}^{6 \mathrm{a}}(\mathrm{HL})$ in $\mathrm{Et}_{2} \mathrm{O}$ and

${ }^{a}$ Università degli Studi di Cagliari, Dipartimento di Chimica Inorganica ed Analitica, Cittadella Universitaria, Monserrato (CA), Italy. E-mail: isaia@unica.it; Fax: +390706754456; Tel: +390706754496

${ }^{b}$ Università degli Studi di Milano, Dipartimento di Chimica Strutturale e Stereochimica Inorganica, via G. Venezian, 21, 20133, Milano, Italy

$\dagger$ CCDC reference numbers for compounds 1-3: CCDC-773676, 773945, and 773946, respectively. For crystallographic data in CIF or other electronic format see DOI: 10.1039/c0dt01409e 1,4-dimethylperhydro-1,4-diazepine-2,3-dithione ${ }^{6 \mathrm{~b}}\left(\mathrm{Me}_{2} \mathrm{dazdt}\right)$ in THF with the separation of the tetrahedral $\mathrm{Hg}$ (II) complexes $\left[\mathrm{HgL}_{2}\right]$ and $\left[\mathrm{Hg}\left(\mathrm{Me}_{2}\right.\right.$ dazdt $\left.) \mathrm{I}_{2}\right]$, respectively. However, the chemical stability and inertness of these complexes strongly limits the possibility of creating a recovery process since the recycling of the donors is difficult.

In this context, we have exploited this synthetic route using the $\mathrm{I}_{2}$-adducts of the antithyroid drugs propylthiouracil (PTU) and methimazole (MeImSH) as oxidizing and complexing agents, Chart 1 . The solvent too has been changed, preferring the use of $\mathrm{CH}_{2} \mathrm{Cl}_{2}$ both to enhance the solubility of the $\mathrm{I}_{2}$-adducts, and to test the oxidative process under hydrophobic conditions. Unlike

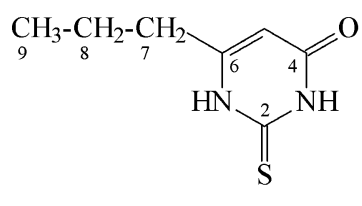

PTU

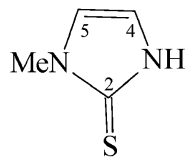

MeImSH
Chart 1 Structures of propylthiouracil (PTU) (6-propyl-2-sulfanylpyrimidin-4-one) and methimazole (MeImSH) (1-methyl-3Himidazole-2-thione). 
Table 1 Crystallographic data and structure refinement details

\begin{tabular}{|c|c|c|c|}
\hline Compound & $\mathrm{HgI}_{2}(\mathrm{PTU})_{2} \cdot \mathrm{MeOH}(\mathbf{1})$ & $\mathrm{HgI}_{2}(\mathrm{PTU})_{2} \cdot \mathrm{HgI}_{2}(\mathbf{2})$ & $\mathrm{Hg}_{2} \mathrm{I}_{4}(\mathrm{MeImSH})_{2}(3)$ \\
\hline Formula & $\mathrm{C}_{15} \mathrm{H}_{24} \mathrm{HgI}_{2} \mathrm{~N}_{4} \mathrm{O}_{3} \mathrm{~S}_{2}$ & $\mathrm{C}_{14} \mathrm{H}_{20} \mathrm{Hg}_{2} \mathrm{I}_{4} \mathrm{~N}_{4} \mathrm{O}_{2} \mathrm{~S}_{2}$ & $\mathrm{C}_{8} \mathrm{H}_{12} \mathrm{Hg}_{2} \mathrm{I}_{4} \mathrm{~N}_{4} \mathrm{~S}_{2}$ \\
\hline Crystal system & Triclinic & Triclinic & Triclinic \\
\hline Space group & $P-1($ no. 2$)$ & $P-1($ no. 2$)$ & $P-1$ (no. 2) \\
\hline$M . W$. & 826.89 & 1249.24 & 1137.12 \\
\hline$a / \AA$ & $8.5811(15)$ & $8.5338(6)$ & $5.5676(7)$ \\
\hline$b / \AA$ & $11.1302(19)$ & $12.8631(9)$ & $9.2909(11)$ \\
\hline$c / \AA$ & $13.3986(23)$ & $13.8786(10)$ & $10.5376(13)$ \\
\hline$\alpha\left(^{\circ}\right)$ & $72.85(1)$ & $67.41(1)$ & $102.52(1)$ \\
\hline$\beta\left({ }^{\circ}\right)$ & $81.90(1)$ & $88.16(1)$ & $90.21(1)$ \\
\hline$\gamma\left({ }^{\circ}\right)$ & $79.70(1)$ & $75.56(1)$ & $100.33(1)$ \\
\hline$V / \AA^{3}$ & $1197.8(4)$ & $1358.7(2)$ & $523.0(1)$ \\
\hline $\mathrm{Z}$ & 2 & 2 & 1 \\
\hline$D_{\mathrm{c}} / \mathrm{Mg} \mathrm{m}^{-3}$ & 2.293 & 3.053 & 3.610 \\
\hline$\mu / \mathrm{mm}^{-1}$ & 9.198 & 16.001 & 20.758 \\
\hline Measured reflections & 17309 & 11385 & 4606 \\
\hline Unique reflections, $R_{\text {int }}$ & $8918,0.051$ & $6673,0.033$ & $2034,0.048$ \\
\hline \multicolumn{4}{|l|}{ Observed reflections } \\
\hline$[I>2 \sigma(I)]$ & 4049 & 4812 & 1860 \\
\hline Min-max transmission factors & $0.173,0.479$ & $0.058,0.326$ & $0.095,0.288$ \\
\hline$R$ [observed reflections] & 0.0557 & 0.0345 & 0.0496 \\
\hline $\mathrm{w} R_{2}$ [all data] & 0.1864 & 0.0809 & 0.1547 \\
\hline Min-max electron density residual $\left(\mathrm{e} / \AA^{3}\right)$ & $-2.70-3.38$ & $-2.01-1.62$ & $-1.99-2.56$ \\
\hline
\end{tabular}

donors HL and $\mathrm{Me}_{2}$ dazdt, drugs PTU and MeImSH, are both available on the market.

Herein we report on the reaction of PTU- $\mathrm{I}_{2}$ and MeImSH$\mathrm{I}_{2}$ with liquid mercury and the X-ray crystal structure determination of neutral mercury(II) complexes $\left[\mathrm{HgI}_{2}(\mathrm{PTU})_{2} \cdot \mathrm{MeOH}\right]$ (1), $\left[\mathrm{HgI}_{2}(\mathrm{PTU})_{2} \cdot \mathrm{HgI}_{2}\right]$ (2), and $\left[\mathrm{Hg}_{2} \mathrm{I}_{4}(\mathrm{MeImSH})_{2}\right]$ (3). With the help of theoretical calculations, we also provide an explanation on the oxidizing properties of PTU- $\mathrm{I}_{2}$ and $\mathrm{MeImSH}-\mathrm{I}_{2}$ adducts.

The reaction of complexes 1, 2, and $\mathbf{3}$ with $\mathrm{Et}_{4} \mathrm{NI}$ to separate compound $\left(\mathrm{Et}_{4} \mathrm{~N}\right)_{2}\left[\mathrm{HgI}_{4}\right]$ in all three cases with the release of free PTU and MeImSH, respectively, is also reported. Moreover, because of the importance of PTU and MeImSH as antithyroid drugs, ${ }^{3}$ the role of intermolecular interactions (hydrogen-bonding donor/acceptor properties) in complexes 1-3 have been investigated.

\section{Results and Discussion}

\section{Synthesis and X-ray structures of complexes 1-3}

The reaction between the $\mathrm{I}_{2}$-adduct of propylthiouracil, PTU- $\mathrm{I}_{2}$ and liquid $\mathrm{Hg}$ (1 : 1 molar ratio) was carried out in $\mathrm{CH}_{2} \mathrm{Cl}_{2}$ solution at room temperature for two days. During this time, the initial dark-red colour of the reaction mixture, due to the charge-transfer adduct PTU- $\mathrm{I}_{2}$, turned to light orange, and gradually, an air-stable pale yellow powder separated from the solution. Treatment of the crude material with a $\mathrm{MeOH}-\mathrm{CHCl}_{3}$ solution $(1: 4 \mathrm{v} / \mathrm{v})$ caused the complete dissolution of the solid; after slow evaporation of the solution, crystals of stoichiometry $\left[\mathrm{HgI}_{2}(\mathrm{PTU})_{2} \cdot \mathrm{MeOH}\right]$ (1) were isolated. Then, for further evaporation of the solution, a red inorganic powder identified as $\mathrm{HgI}_{2}$ was obtained. Conversely, crystallization of the yellow crude material from $\mathrm{CHCl}_{3}$ yielded the crystalline complex $\left[\mathrm{HgI}_{2}(\mathrm{PTU})_{2} \cdot \mathrm{HgI}_{2}\right]$ (2). The crystallographic data and the crystal structure of compound $\mathbf{1}$ are reported in Table 1 and Fig. 1, respectively.
The central mercury(II) ion is coordinated in a tetrahedral fashion by two iodides and two neutral PTU molecules acting as monodentate $S$-donor ligands similarly to what is found in gold(I) complexes $\left[\mathrm{R}_{3} \mathrm{PAu}(\mathrm{PTU})\right]\left(\mathrm{R}=\mathrm{Et},{ }^{7}\right.$ cyclohexyl $\left.^{8}\right)$ with anionic PTU that, to the best of our knowledge, are the only other PTU metal complexes structurally characterized so far. The presence of several groups capable of interacting via $\mathrm{H}$ bonds influences the orientation of the PTU moieties within the complex. An intramolecular hydrogen bond between (N1)H1 and I1 (Fig. 1, Table 2) affects the arrangement of only one of the two PTU molecules, the other one being arranged in an almost anti-parallel way to the former probably because of the $\mathrm{H}$ bonds involving the co-crystallized methanol molecule. In fact, the hydroxyl group of the methanol behaves as an acceptor towards hydrogen $\mathrm{H} 3 \mathrm{~N}$ and as a donor in the direction of $\mathrm{I} 2$ atom. ${ }^{9}$ This orientation of the PTU moieties also allows maximizing multiple intermolecular H-bonds that organize the complex molecules in the strip-like packing described in Fig. 2 and by the graph-set analysis $^{10}$ of hydrogen bond patterns (Fig. 3). It is interesting to highlight that the intra-molecular hydrogen bond $(\mathrm{N} 1) \mathrm{H} 1 \cdots \mathrm{I} 1$ is maintained despite the fact that the complex is obtained by crystallization from a chloroform solution containing methyl alcohol.

The X-ray structure determination of $\mathbf{2}$ shows the rare presence in the asymmetric unit of two different mercury(II) species, namely $\left[\mathrm{HgI}_{2}(\mathrm{PTU})_{2}\right]$ and $\mathrm{HgI}_{2}$, as shown in Fig. 4. Crystallographic data are reported in Table 1 . The structure of complex $\left[\mathrm{HgI}_{2}(\mathrm{PTU})_{2}\right]$ in 2 closely resembles the one previously discussed. In this case the PTU moieties also give rise to a number of intra- and intermolecular H-bonds (Table 2) that affect the orientation of the PTU molecules both in the asymmetric unit as well as in the packing, as described in Fig. 5 and by the graph-set analysis ${ }^{10}$ of hydrogen bond patterns in Fig. 6.

The most remarkable and noteworthy feature that distinguishes compound $\mathbf{2}$ is the presence of the nearly linear $\mathrm{HgI}_{2}$ molecules encapsulated in the crystal packing of the $\left[\mathrm{HgI}_{2}(\mathrm{PTU})_{2}\right]$ 
Table 2 Selected hydrogen bond distances $(\AA)$ and angles $\left(^{\circ}\right)$ for complexes 1-3. The letters in brackets refer to the contacts shown in Fig. 2 and Fig. 3 (compound 1), and Fig. 4 and Fig. 5 (compound 2)

\begin{tabular}{|c|c|c|c|c|c|}
\hline Compound & $\mathrm{X}-\mathrm{H}$ & $\mathrm{H} \cdots \mathrm{Y}$ & $\mathrm{X} \cdots \mathrm{Y}$ & $\mathrm{X}-\mathrm{H}-\mathrm{Y}$ & Symmetry code \\
\hline \multicolumn{6}{|l|}{1} \\
\hline $\mathrm{N} 1-\mathrm{H} 1 \cdots \mathrm{I} 1$ & 0.86 & 2.76 & $3.620(6)$ & 176 & \\
\hline $\mathrm{N} 2-\mathrm{H} 2 \cdots \mathrm{O} 2(\mathbf{a})$ & 0.86 & 1.95 & $2.783(8)$ & 162 & $2-x,-y, 1-z$ \\
\hline N3-H3N ‥O & 0.86 & 1.97 & $2.799(10)$ & 161 & \\
\hline $\mathrm{N} 4-\mathrm{H} 4 \cdots \mathrm{O} 1(\mathbf{c})$ & 0.86 & 1.93 & $2.771(8)$ & 166 & $1-\mathrm{x}, 1-\mathrm{y}, 1-\mathrm{z}$ \\
\hline \multicolumn{6}{|l|}{2} \\
\hline N3-H3N ‥I2 & 0.86 & 2.77 & $3.631(5)$ & 177 & \\
\hline $\mathrm{N} 2-\mathrm{H} 2 \cdots \mathrm{O} 2(\mathbf{a})$ & 0.86 & 1.92 & $2.773(6)$ & 170 & $2-\mathrm{x}, 1-\mathrm{y},-\mathrm{z}$ \\
\hline $\mathrm{N} 4-\mathrm{H} 4 \cdots \mathrm{O} 1(\mathbf{b})$ & 0.86 & 1.92 & $2.743(7)$ & 161 & $2-x,-y,-z$ \\
\hline $\mathrm{N} 1-\mathrm{H} 1 \cdots \mathrm{I} 4$ & 0.86 & 2.89 & $3.745(5)$ & 176 & $2-\mathrm{x},-\mathrm{y},-\mathrm{z}$ \\
\hline \multicolumn{6}{|l|}{3} \\
\hline $\mathrm{N} 1-\mathrm{H} 1 \cdots \mathrm{S} 1$ & 0.86 & 2.59 & 3.424(11) & 162 & $1-\mathrm{x}, 1-\mathrm{y},-\mathrm{z}$ \\
\hline
\end{tabular}

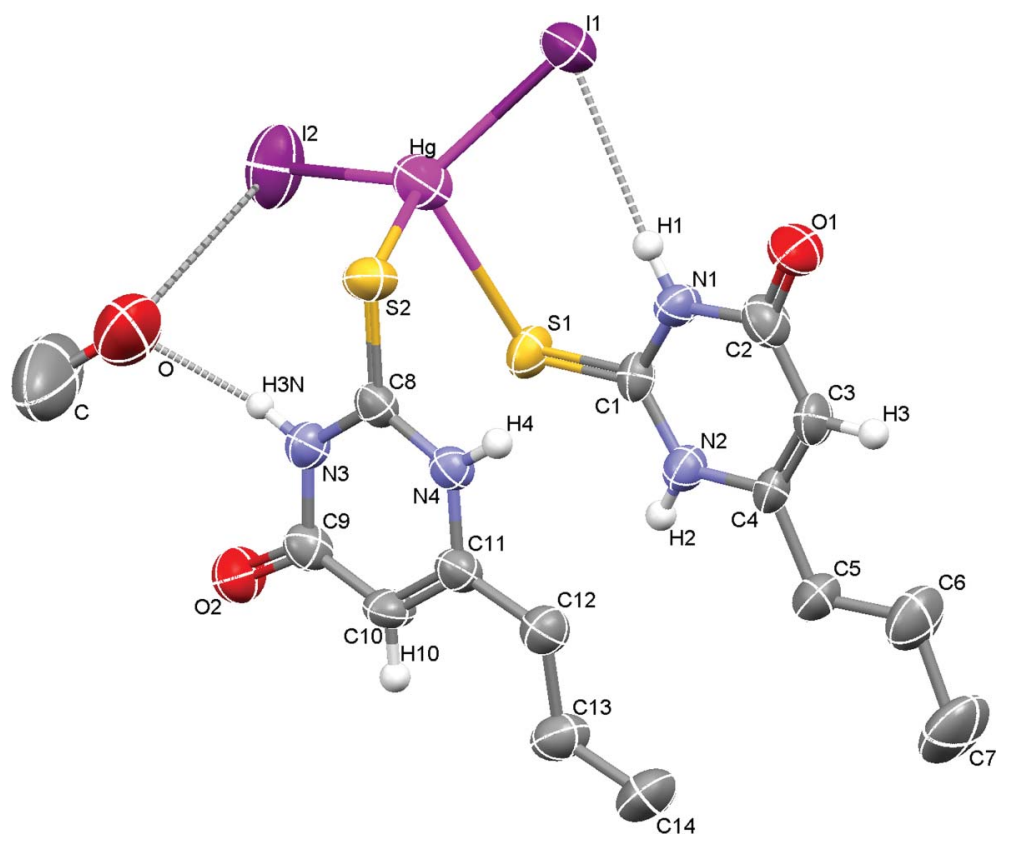

Fig. 1 Molecular view of compound $\left[\mathrm{HgI}_{2}(\mathrm{PTU})_{2} \cdot \mathrm{MeOH}\right](\mathbf{1})$. For better clarity, the hydrogen atoms of the propyl appendages have been omitted. Displacement ellipsoids are drawn at 50\% probability. Hg-I1 2.6916(8), Hg-I2 2.6483(9), Hg-S1 2.804(2), Hg-S2 2.647(2), S1-C1 1.691(7), S2-C8 1.712(7) Å; I1-Hg-I2 131.71(3), S1-Hg-S2 94.15(6), I1-Hg-S1 106.01(5), I2-Hg-S1 98.68(5), I1-Hg-S2 103.12(5), I2-Hg-S2 115.89(5), Hg-S1-C1 $110.1(3), \mathrm{Hg}-\mathrm{S} 2-\mathrm{C} 8100.5(2)^{\circ}$.

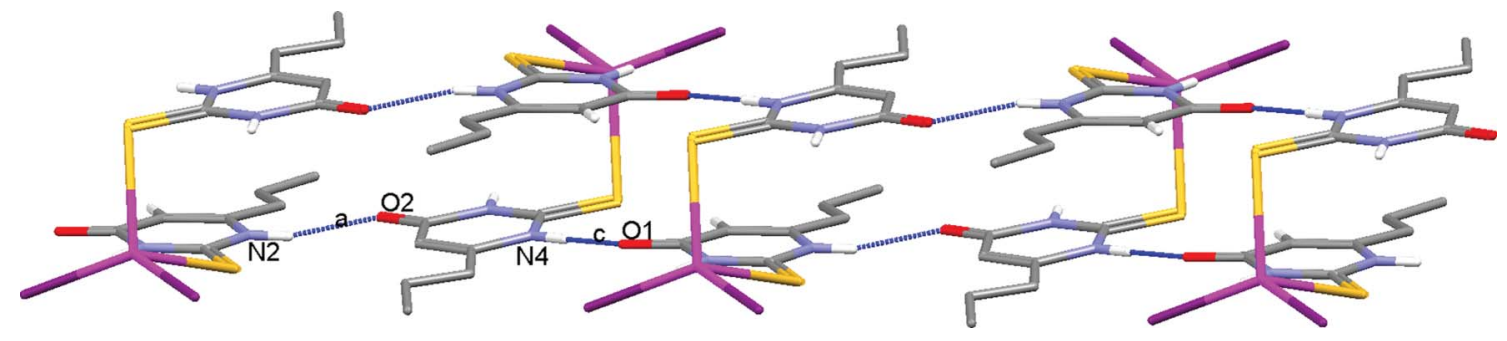

Fig. 2 The strip-like packing of complex 1 guided by the strong intermolecular H-bonds a and c (see Table 2). For better clarity, the methanol molecules and the hydrogen atoms of the propyl appendages have been omitted.

complex molecules. As shown in Fig. 7, the $\left[\mathrm{HgI}_{2}(\mathrm{PTU})_{2}\right]$ complex molecules assemble in the crystal giving rise to a framework, held together by hydrogen bonds, which displays cavities occupied by $\mathrm{HgI}_{2}$ molecules that only slightly interact with the $\left[\mathrm{HgI}_{2}(\mathrm{PTU})_{2}\right]$ framework. ${ }^{11}$ This is confirmed by the evidence that the two $\mathrm{Hg}-\mathrm{I}$ bond distances [Hg2-I3, 2.5776(5); Hg2-I4, 2.5861(5) Å] are comparable with those found in gaseous $\mathrm{HgI}_{2}$ [2.57(4) $\AA$ ]. Structural analysis of compounds $\mathbf{1}$ and $\mathbf{2}$ highlights the role of the crystallization solvent/s, in fact, the use of the mixture methanolchloroform instead of chloroform results in the inclusion of methanol molecules and the exclusion of $\mathrm{HgI}_{2}$ molecules in the crystal packing of compound $\mathbf{1}$. 

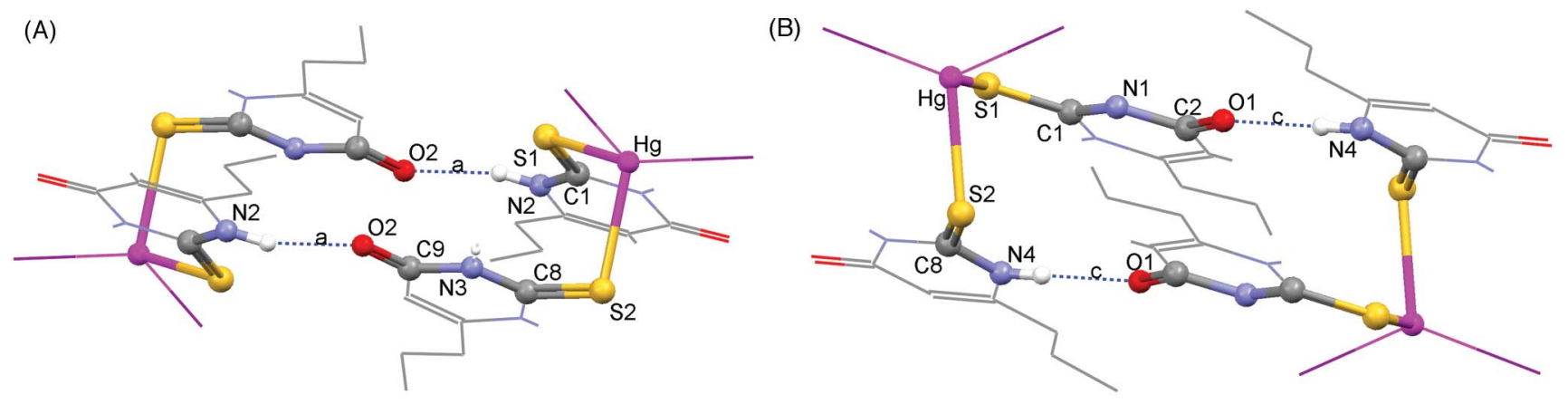

(C)

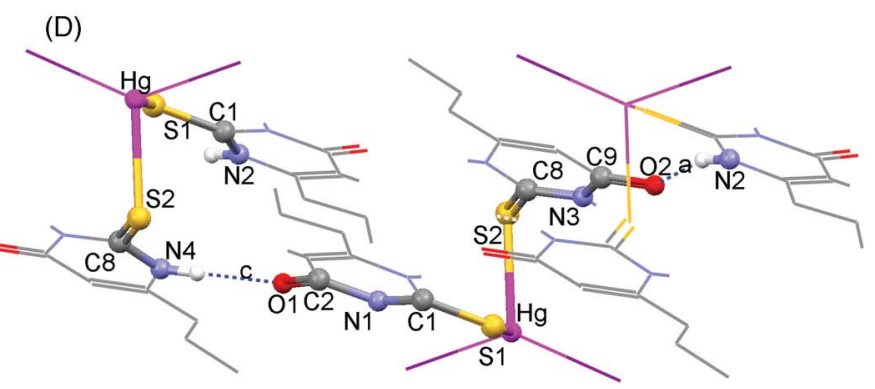

(E)

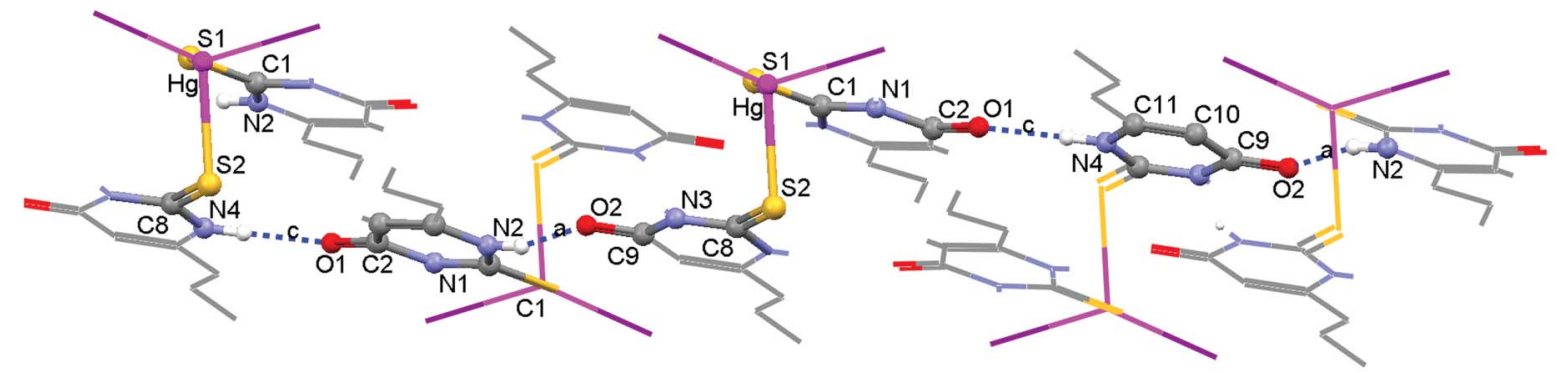

Fig. 3 Main intermolecular hydrogen bond patterns in compound 1: (A) $R_{2}^{2}(20) \_\mathrm{a}$; (B) $R_{2}^{2}(20) \_\mathrm{c} ;(\mathrm{C}) C_{2}^{2}(12) \_\mathrm{a}, \mathrm{c}$; (D) $C_{2}^{2}(20) \_\mathrm{a}, \mathrm{c}$; (E) $C_{4}^{4}(32) \_\mathrm{a}, \mathrm{c}, \mathrm{a}$, c; (see also Table 2).

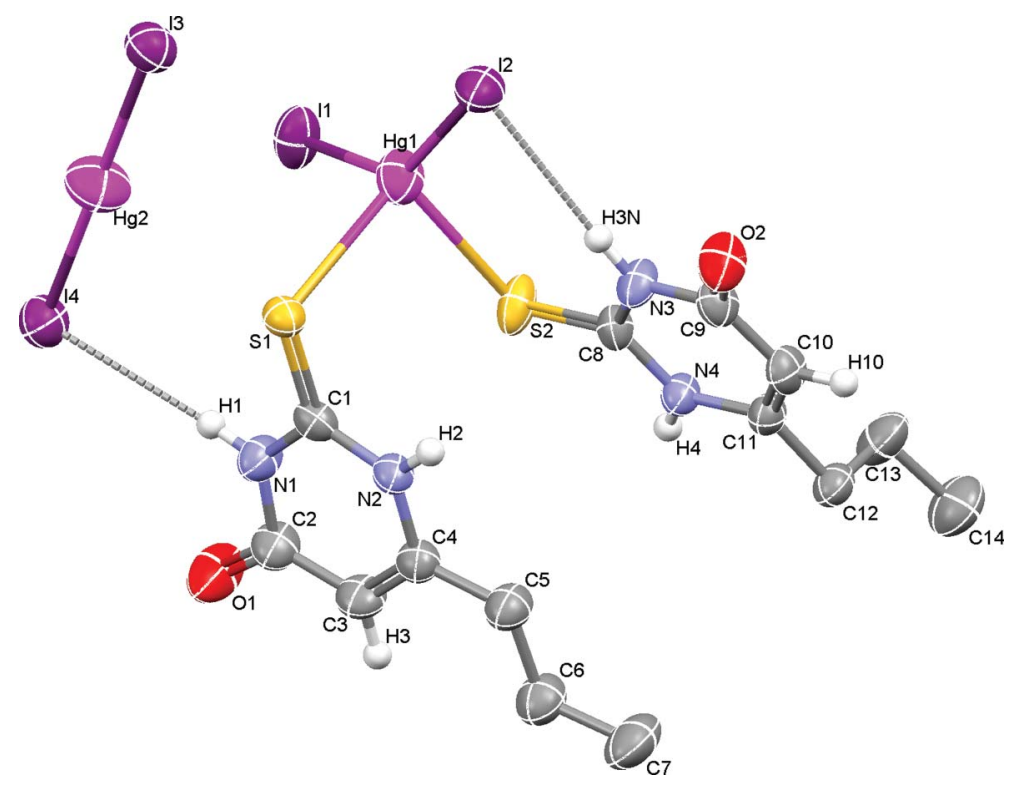

Fig. 4 Molecular view of compound $\left[\mathrm{HgI}_{2}(\mathrm{PTU})_{2} \cdot \mathrm{HgI}_{2}\right]$ (2). For better clarity, the hydrogen atoms of the propyl appendages have been omitted. Displacement ellipsoids are drawn at 50\% probability. Hg1-I1 2.6754(5), Hg1-I2 2.6479(5), Hg1-S1 2.843(1), Hg1-S2 2.656(2), S1-C1 1.698(5), S2-C8 1.676(5), Hg2-I3 2.5776(5), Hg2-I4 2.5861(5) Å; I1-Hg1-I2 140.85(2), S1-Hg1-S2 95.92(5), I1-Hg1-S1 103.21(3), I2-Hg1-S1 99.58(3), I1-Hg1-S2 95.28(3), I2-Hg1-S2 113.61(3), Hg1-S1-C1 101.8(2), Hg1-S2-C8 111.7(2), I3-Hg2-I4 179.72(2) ${ }^{\circ}$. 


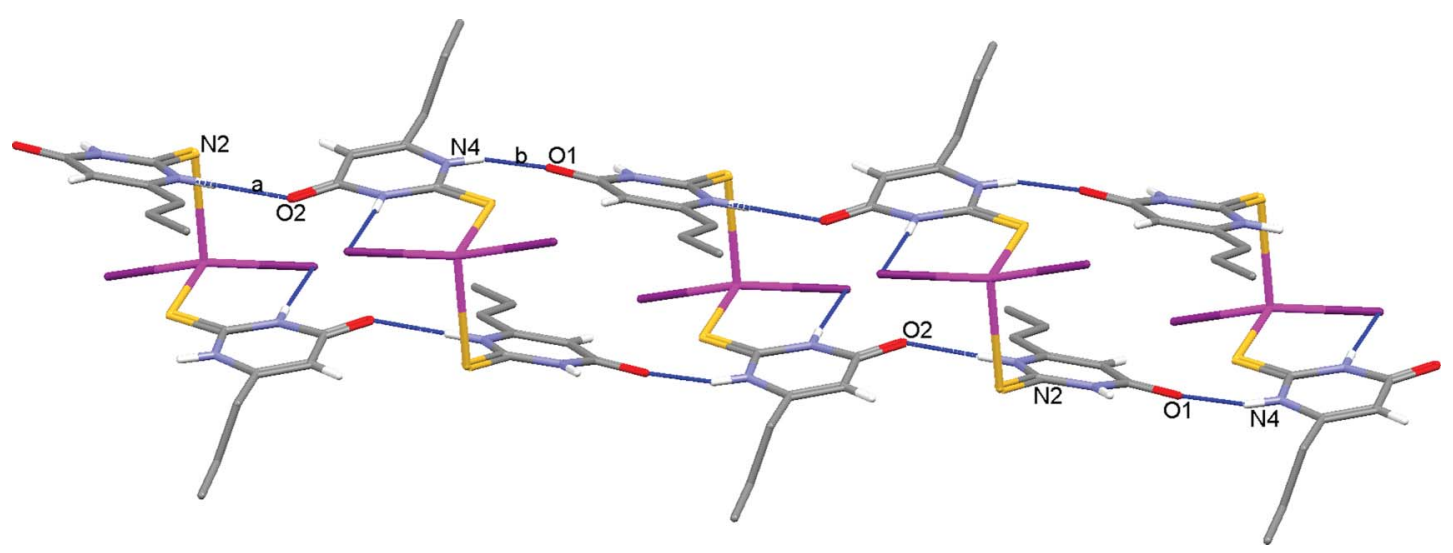

Fig. 5 The strip-like packing of complex 2 guided by the strong intermolecular H-bonds a and b (see Table 2). For better clarity, the hydrogen atoms of the propyl appendages and the $\mathrm{HgI}_{2}$ molecules have been omitted.

(A)

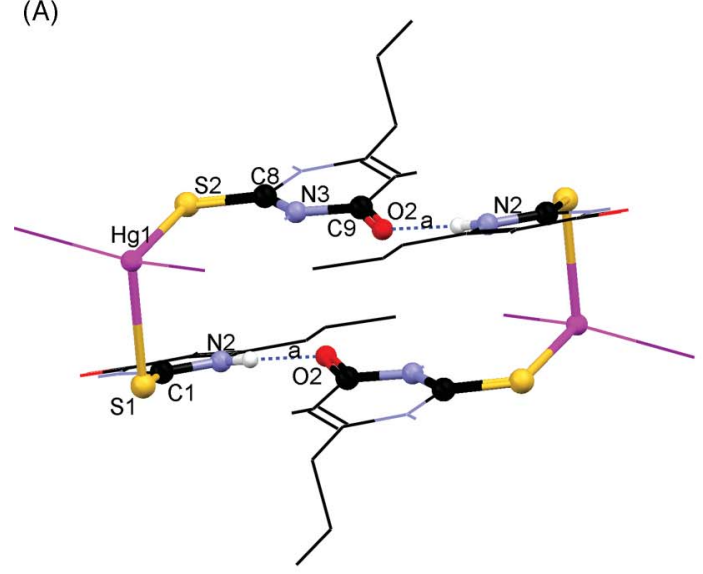

(C)

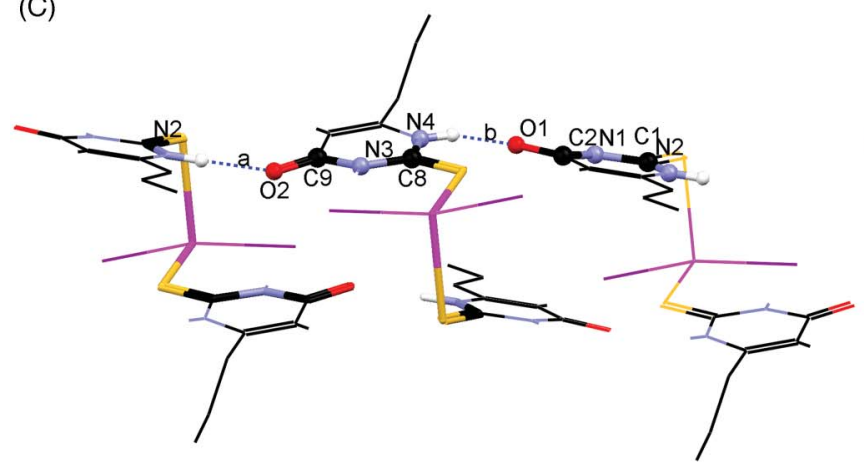

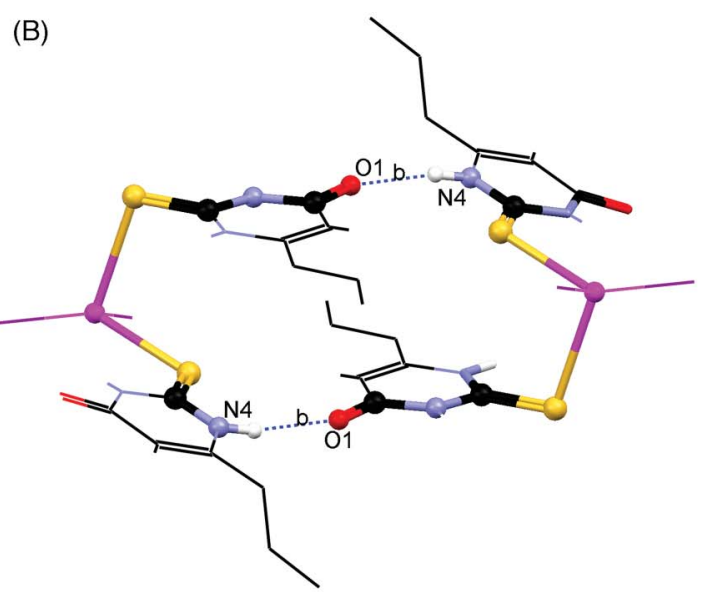

(D)

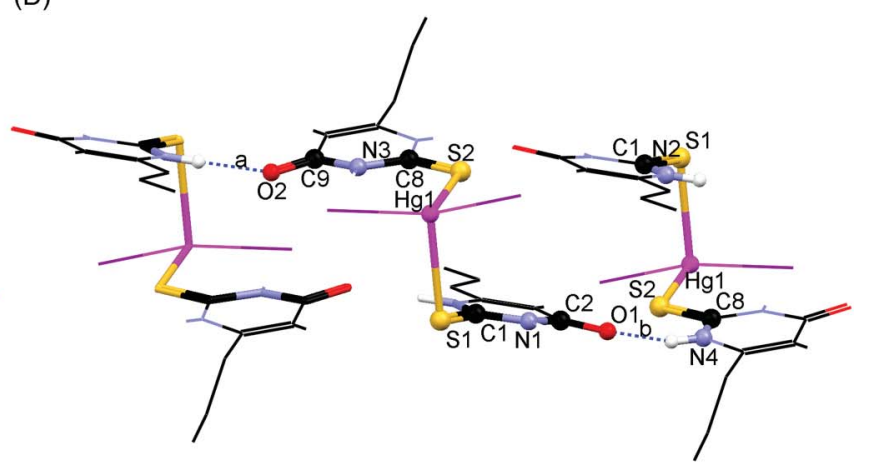

(E)

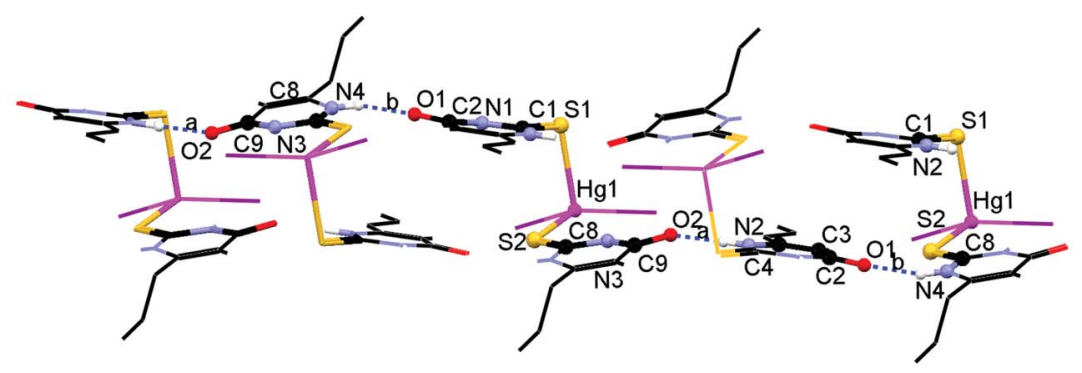

Fig. 6 Main intermolecular hydrogen bond patterns in compound 2: (A) $R_{2}^{2}(20) \_\mathrm{a}$; (B) $R_{2}^{2}(20) \_\mathrm{b}$; (C) $C_{2}^{2}(12) \_\mathrm{a}, \mathrm{b}$; (D) $C_{2}^{2}(20) \_\mathrm{a}, \mathrm{b}$; (E) $C_{4}^{4}(32) \_\mathrm{a}, \mathrm{b}$, a, b; (see also Table 2). 


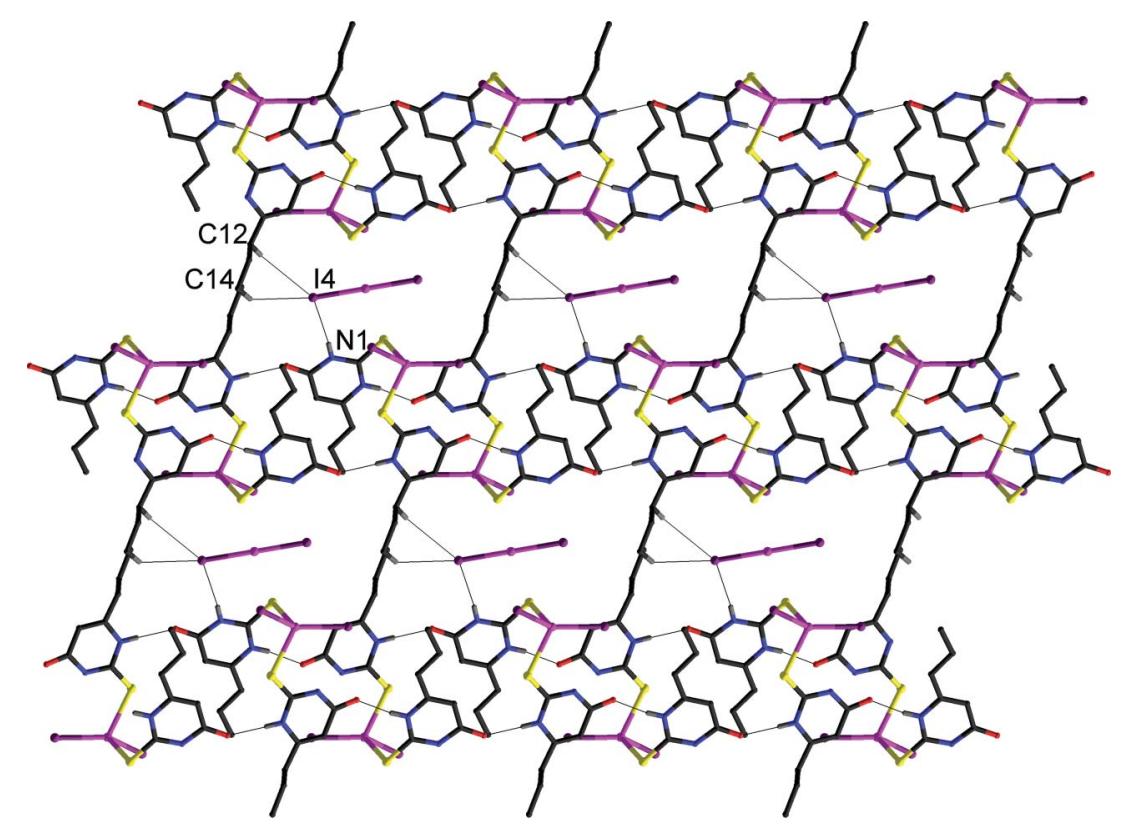

Fig. 7 View along $\left[\begin{array}{lll}1 & 0 & 0\end{array}\right]$ of the crystal packing of compound $\left[\mathrm{HgI}_{2}\left(\mathrm{PTU}_{2} \cdot \mathrm{HgI}_{2}\right](2)\right.$. Only hydrogen atoms involved in the shown interactions are reported for clarity. Interactions involving $\mathrm{HgI}_{2}$ moieties: $\mathrm{H} 12 \mathrm{~b} \cdots \mathrm{I} 4,3.27 ; \mathrm{H} 14 \mathrm{a} \cdots \mathrm{I} 4,3.32 ; \mathrm{H} 1 \cdots \mathrm{I} 4,2.89 \AA$ A hydrogen bonds responsible for the $\mathrm{HgI}_{2}(\mathrm{PTU})_{2}$ framework are described in Fig. 5 and Fig. 6.

The reactions of the $\mathrm{I}_{2}$ adduct of methimazole MeImSH- $\mathrm{I}_{2}$ and liquid $\mathrm{Hg}$ performed in $\mathrm{CH}_{2} \mathrm{Cl}_{2}$ in different molar ratios (from $1: 1$ to $3: 1)$ always yielded the dinuclear complex $\left[\mathrm{Hg}_{2} \mathrm{I}_{4}(\mathrm{MeImSH})_{2}\right]$ (3) whose structure, determined by means of single crystal X-ray diffraction, is shown in Fig. 8.

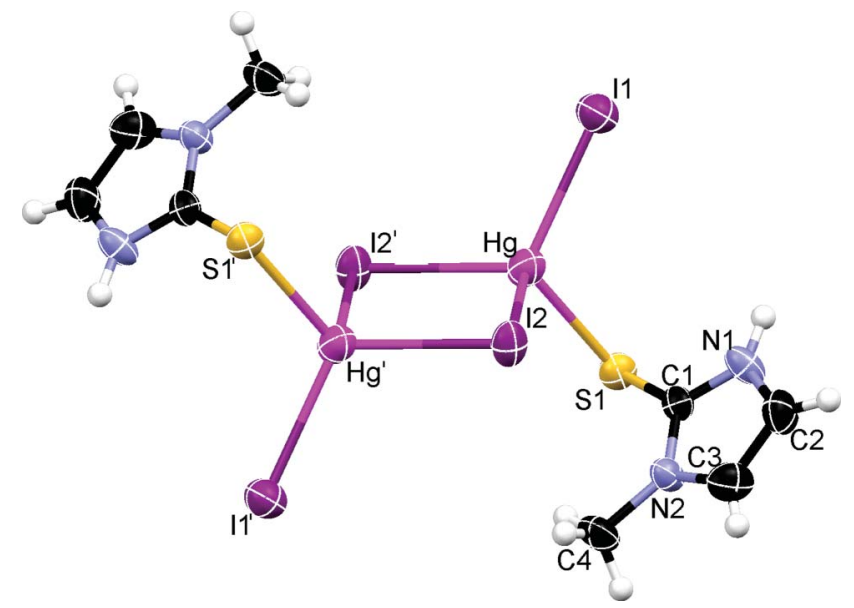

Fig. 8 Molecular view of compound $\left[\mathrm{Hg}_{2} \mathrm{I}_{4}(\mathrm{MeImSH})_{2}\right]$ (3). Displacement ellipsoids are drawn at $50 \%$ probability. Symmetry codes: ' = 1-x, 1-y, 1-z. Hg-I1 2.7208(10), Hg-I2 2.7956(10), Hg-I2' 2.9752(10), Hg-S1 2.523(3), S1-C1 1.738(10) Å; I1-Hg-I2 115.42(3), I1-Hg-I2' 109.33(3), I1-Hg-S1 113.17(7), I2-Hg-S1 118.81(7), I2'-Hg-S1 102.82(6), $\mathrm{Hg}-\mathrm{S} 1-\mathrm{C} 197.9(3)^{\circ}$.

Complex 3 consists of dimeric $\left[\mathrm{Hg}_{2} \mathrm{I}_{4}(\mathrm{MeImSH})_{2}\right]$ molecules located about crystallographic inversion centers; this dimeric arrangement is quite common, and several compounds featuring similar $\mathrm{Hg}_{2} \mathrm{~S}_{2} \mathrm{X}_{4}$ cores can be found in the literature $(\mathrm{X}=\mathrm{Cl}, \mathrm{Br}$, I). ${ }^{12}$ Differently from what was observed in previously discussed
PTU complexes $\mathbf{1}$ and 2, methimazole molecules establish only one inter-molecular $\mathrm{H}$-bond involving adjacent molecules, thus forming infinite chains in the crystal, Fig. 9.

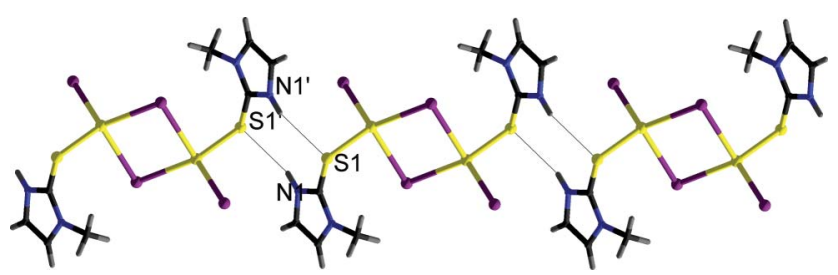

Fig. 9 Packing view of compound 3 showing the infinite chains generated by $\mathrm{N} 1-\mathrm{H} 1 \cdots \mathrm{S} 1^{\prime} \mathrm{H}$-bonds $\left(\mathrm{H} \cdots \mathrm{S} 1^{\prime} 2.59 \AA\right.$; symmetry code ${ }^{\prime}=1-\mathrm{x}$, $1-\mathrm{y},-\mathrm{z})$.

The experimental data show that both $\mathrm{I}_{2}$-adducts of drugs MeImSH and PTU can easily oxidize liquid mercury to mercuric ion in mild reaction conditions with a two-electron transfer process according to reaction (1) and (2), respectively.

$$
\begin{aligned}
& \text { MeImSH-I }{ }_{2}+\mathrm{Hg} \stackrel{\mathrm{CH}_{2} \mathrm{Cl}_{2}}{\longrightarrow} \mathrm{HgI}_{2}(\mathrm{MeImSH}) \\
& 2 \mathrm{PTU}-\mathrm{I}_{2}+2 \mathrm{Hg} \stackrel{\mathrm{CH}_{2} \mathrm{Cl}_{2}}{\longrightarrow} \mathrm{HgI}_{2}(\mathrm{PTU})_{2}+\mathrm{HgI}_{2}
\end{aligned}
$$

Useful information to understand the higher oxidizing ability of $\mathrm{I}_{2}$-adducts of $S$-donor molecules, compared to that of molecular iodine, can be inferred by the structural and electronic properties of this class of compounds. Analysis of the X-ray crystal structures of adducts $\mathrm{MeImSH}-\mathrm{I}_{2}{ }^{13}$ and PTU- $\mathrm{I}_{2}{ }^{14}$ highlights the mutual effect that these $S$-donor (DS) exerts on the $\mathrm{I}_{2}$ molecule and vice versa. ${ }^{4}$ Adduct formation results in a marked elongation of the I-I bond (2.991 and $2.826 \AA$, respectively) compared to that observed in crystalline $\mathrm{I}_{2}\left(2.715 \AA\right.$, at $\left.-163.1^{\circ} \mathrm{C}\right)$ and in the formation of a $\mathrm{S}-\mathrm{I}$ 
bond whose length (2.593 and $2.780 \AA$, respectively) is significantly shorter than the sum of the van der Waals radii for sulfur $(1.80 \AA)$ and iodine (1.98 $\AA$ ). As a consequence, the $\mathrm{C}-\mathrm{S}$ bond $(1.725 \AA$ in MeImSH-I $\mathrm{I}_{2}$ and $1.696 \AA$ in PTU- $_{2}$ ) is also elongated indicating a reduced $\mathrm{C}=\mathrm{S}$ double-bond character. These data are indicative of the strong donor-acceptor interaction in MeImSH-I $\mathrm{I}_{2}$ and that this adduct could be better described as a polarized system with a partial positive charge $\delta^{+}$associated with the MeImSH-I moiety and the terminal I atom carrying a partial negative charge $\delta^{-}$, i.e. $(D S-I)^{\delta+} \ldots I^{\delta-}$. Conversely, in the case of PTU-I $I_{2}$ adduct where the extent of electron transfer to $\mathrm{I}_{2}$ from PTU is much lower, a smaller charge separation is expected (see below). ${ }^{15}$

\section{Quantum Chemical Calculations}

DFT calculations were carried out to evaluate the entity of the charge separation in MeImSH- $\mathrm{I}_{2}$ and $\mathrm{PTU}-\mathrm{I}_{2}$. Natural charges ${ }^{16}$ calculated at the experimental structural geometry clearly show that in the former adduct the charge transfer from the organic donor DS to the $\mathrm{I}_{2}$ unit is remarkably higher than in the latter ( 0.386 and $0.238 \mathrm{e}$, respectively), resulting in a corresponding decrease in the I-I bond order, which can be evaluated by means of Wiberg bond indexes ${ }^{17}$ (0.609 and 0.757 in MeImSH-I ${ }_{2}$ and PTU- ${ }_{2}$, respectively). As a consequence of the increased charge transfer, the natural charge on the terminal iodine atom in adducts is remarkably more negative in MeImSH-I $\mathrm{I}_{2}$ than in PTU- $\mathrm{I}_{2}(-0.367$ and -0.206 e, respectively). These results clearly show that adduct formation results in a permanent charge separation between the iodine atoms of 0.348 and 0.175 e for MeImSH-I ${ }_{2}$ and PTU- ${ }_{2}$, respectively, and thus radically changing their reactivity when compared to that of molecular $\mathrm{I}_{2}$. On these grounds it seems reasonable to hypothesize ${ }^{18}$ that reactions (1) and (2) should proceed via a mechanism of oxidative addition with the (DSI $)^{\delta+}$ moiety acting as electrophilic agent and hence formation of $\mathrm{Hg}-\mathrm{I}$ bonds followed by displacement of DS and subsequent $S$ coordination to the mercury ion:

$$
[\mathrm{DS}-\mathrm{I}]^{\delta+} \cdots \mathrm{I}^{\delta-}+\mathrm{Hg} \rightarrow[\mathrm{DS}-\mathrm{I}-\mathrm{Hg}]^{+} \mathrm{I}^{-} \rightarrow\left[\mathrm{HgI}_{2}(\mathrm{DS})\right]
$$

The function of the donor is double. In addition to polarizing the bound $\mathrm{I}_{2}$ molecule, it must also act as a good coordinating agent toward the mercury(II) ion. In order to investigate the nature of $(\mathrm{DS}-\mathrm{I})^{\delta+}$ species, the geometries of the two model iodosulfide cations $(\mathrm{MeImSH}-\mathrm{I})^{+}$and $(\mathrm{PTU}-\mathrm{I})^{+}$were optimized. In both cases the S-I group is roughly perpendicular to the plane of the organic donor, with $\mathrm{C}-\mathrm{S}-\mathrm{I}$ angles slightly larger than 100 degrees [101.67 and 104.66 for $(\mathrm{MeImSH}-\mathrm{I})^{+}$and (PTU-I) ${ }^{+}$, respectively]. The Kohn-Sham (KS) highest occupied and lowest unoccupied orbitals of the two cations show similar features in the two investigated cations [see Fig. 10 for $(\mathrm{MeImSH}-\mathrm{I})^{+}$], the KS-LUMO being antibonding with respect to the S-I bond. The NBO charge distribution calculated shows the sulfur atom neutral or slightly positive [0.078 and 0.128 e for (MeImSH-I $)^{+}$ and (PTU-I $)^{+}$, respectively] and the iodine atom positively charged [0.162 and 0.241 e for (MeImSH-I) ${ }^{+}$and (PTU-I) ${ }^{+}$. Therefore, it is conceivable that zerovalent mercury might interact with the electrophilic I atom weakening the S-I bond of the (DS-I $)^{+}$moiety, in agreement with the reaction scheme (3) discussed above.
Table $3{ }^{13} \mathrm{C}$ NMR data of donors PTU and MeImSH, and complexes 1-3, $\left(\delta \text { in ppm, } \mathrm{CDCl}_{3} / \mathrm{CD}_{3} \mathrm{OD} 4: 1 \mathrm{v} / \mathrm{v}, 25^{\circ} \mathrm{C}\right)^{a}$

\begin{tabular}{lllll}
\hline PTU & $\mathbf{1}$ & $\mathbf{2}$ & MeImSH & $\mathbf{3}$ \\
\hline $176.0(\mathrm{CS})$ & 174 & 173.9 & $163.3(\mathrm{CS})$ & 154.1 \\
$162.4(\mathrm{CO})$ & 161.2 & 161.2 & $114.2(\mathrm{C} 4)$ & 118.0 \\
$157.1(\mathrm{C} 6)$ & 157.1 & 157.0 & $120.0(\mathrm{C} 5)$ & 122.9 \\
$103.8(\mathrm{C} 5)$ & 104.6 & 104.4 & $34.0(\mathrm{NMe})$ & 36.1 \\
$33.2(\mathrm{C} 7)$ & 33.8 & 33.8 & & \\
$20.1(\mathrm{C} 8)$ & 20.2 & 20.2 & \\
$12.0(\mathrm{C} 9)$ & 12.6 & 12.7 & \\
\multicolumn{5}{l}{ Band assignment in parenthesis. } \\
\hline
\end{tabular}
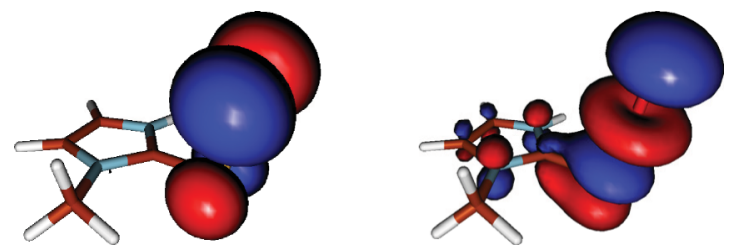

Fig. 10 Representations of Kohn-Sham HOMO (left) and LUMO (right) calculated for the model cation $(\mathrm{MeImSH}-\mathrm{I})^{+}$. Isosurface contour value $0.05 \mathrm{e}$.

\section{${ }^{13}$ C NMR spectra}

The ${ }^{13} \mathrm{C}$ NMR spectral data for complexes 1-3 along with those for the free PTU and MeImSH are listed in Table 3. As a consequence of donors $S$-coordination to the mercury(II) center the CS carbon is expected to be the most sensitive to coordination, in keeping with the reduction of the p-electron density in the $\mathrm{C}=\mathrm{S}$ bond and an increase in the double bond character in the thioamide $\mathrm{C}(\mathrm{S})$ $\mathrm{NH}$ moiety. ${ }^{12 a}$ In complex 3 the CS carbon has an upfield shift of 9.2 ppm whereas carbons $\mathrm{C}(4)$ and $\mathrm{C}(5)$ are slightly downfield shifted (3.8 and 2.9 ppm, respectively). As expected complexes 1 and 2 show similar values of chemical shift, the CS carbon is only slighted affected by ligand $S$-coordination to the metal (upfield shift of $2.0 \mathrm{ppm}$ in 1), the $\mathrm{CO}$ carbon shows an upfield shift too (1.2 ppm in 1) whereas the propyl carbon atoms result unaffected by the coordination process. The upfield shift of the CS carbon in the complexes mirrors the strength of the ligand to metal interaction as evidenced by the $\mathrm{Hg}-\mathrm{S}$ bond distance (complexes 1 and 2: mean value $2.738 \AA$, complex 3: $2.523 \AA$ ).

\section{Reactivity of complexes 1-3 towards tetraethylammonium iodide}

The reaction of complexes 1-3 with $\mathrm{Et}_{4} \mathrm{NI}$ in a $1: 4$ molar ratio $\left(\mathrm{CHCl}_{3}-\mathrm{MeOH} 4: 1 \mathrm{v} / \mathrm{v}\right)$ proceeds very fast with the immediate formation of a pale yellow solid that was identifies as $\left(\mathrm{Et}_{4} \mathrm{~N}\right)_{2}\left[\mathrm{HgI}_{4}\right]$ The ${ }^{13} \mathrm{C}$ NMR spectra of the filtered mixtures revealed the presence of uncoordinated PTU or MeImSH and the carbon signals of the $\mathrm{Et}_{4} \mathrm{~N}^{+}$cation. No signal attributable to Hg-coordinated PTU or MeImSH molecules was detectable. The reported dissolution technique (eqs. 1 and 2) could be easily applied to the recovery of mercury from waste electrical and electronic equipment scrap, the nature of the complexes obtained makes it possible the recycling of the donors and the separation of the mercury as tetraiodomercurate anion. 


\section{Conclusions}

We have shown that under mild conditions the reaction of adducts PTU-I ${ }_{2}, \mathrm{MeImSH}-\mathrm{I}_{2}$ with liquid mercury, in $\mathrm{CH}_{2} \mathrm{Cl}_{2}$, leads to the oxidative dissolution of the metal, the X-ray crystal structure of the isolated mercury(II) complexes $\left[\mathrm{HgI}_{2}(\mathrm{PTU})_{2} \cdot \mathrm{MeOH}\right]$ (1), $\left[\mathrm{HgI}_{2}(\mathrm{PTU})_{2} \cdot \mathrm{HgI}_{2}\right]$ (2), and $\left[\mathrm{Hg}_{2} \mathrm{I}_{4}(\mathrm{MeImSH})_{2}\right]$ (3) has been solved. Interestingly, complex 2 shows almost linear molecules of $\mathrm{HgI}_{2}$ results encapsulated in the crystal packing enfolded by the hydrophobic propyl appendages of coordinated units of PTU. Complexes 1-3 readily react with $\mathrm{Et}_{4} \mathrm{NI}$ to quantitatively precipitate the mercuric ion as $\left(\mathrm{Et}_{4} \mathrm{~N}\right)_{2}\left[\mathrm{HgI}_{4}\right]$ with the release of free PTU or MeImSH. The oxidation of mercury(0) to mercury(II) requires a two-electron transfer process accomplished by an oxidative addition from the "activated" iodine moiety. The oxidizing and complexing properties of MeImSH-I $\mathrm{I}_{2}$ and PTU- $\mathrm{I}_{2}$ have been interpreted considering the $S$-donor to $\mathrm{I}_{2}$ interaction that leads to a charge separation along the DS-I-I moiety to form a $(\mathrm{DS}-\mathrm{I})^{\delta+} \ldots \mathrm{I}^{\delta-}$ polarized system. Lastly, an examination of $S$ coordination of PTU and MeImSH to the $\mathrm{HgI}_{2}$-moiety reveals that in PTU both $\mathrm{NH}$ imido groups and the $\mathrm{CO}$ group act as hydrogen bond donors and acceptor, respectively, whereas in MeImSH the imido group acts as hydrogen bond donor and the sulfur atom, in addition to binding the metal center, acts as an acceptor too. Since inactivation of enzyme thyroid peroxidase (TPO) by PTU and $\mathrm{MeImSH}$ is reported to occur through drug $S$-coordination to the Fe(III)-center of TPO assisted by hydrogen bonding with a histidine residue of the TPO protein, ${ }^{19}$ the different hydrogenbonding donor/acceptor properties shown by PTU and MeImSH could play a role in orienting the amino acid residues in TPO, and, therefore, in differentiating drug mechanisms of action.

\section{Experimental Section}

\section{General methods and materials}

All reagents for the syntheses were purchased from SigmaAldrich and used without further purification. Iodine adducts of methimazole (MeImSH-I ${ }_{2}$ ) and propylthiouracil (PTU-I ${ }_{2}$ ) were synthesized according to procedures reported in references 13 and 14, respectively. Elemental analyses were obtained using a Fisons Instruments 1108 CHNS elemental analyzer. FTIR spectra (4000$400 \mathrm{~cm}^{-1}$ ) were acquired as $\mathrm{KBr}$ discs on a thermo-Nicolet 5700 spectrometer. ${ }^{1} \mathrm{H}$ and ${ }^{13} \mathrm{C}$ NMR spectra were recorded on a Varian Unity 300 spectrometer, chemical shifts are reported in ppm $(\delta)$ downfield from TMS using the same solvents as internal reference.

\section{Synthesis of $\left[\mathrm{HgI}_{2}(\mathrm{PTU})_{2} \cdot \mathrm{MeOH}\right](1)$}

A mixture of PTU- $\mathrm{I}_{2}(0.100 \mathrm{~g}, 0.236 \mathrm{mmol})$ and liquid mercury $(0.047 \mathrm{~g}, 0.236 \mathrm{mmol})$ in $80 \mathrm{~mL}$ of $\mathrm{CH}_{2} \mathrm{Cl}_{2}$ was stirred at room temperature for two days. The resulting air-stable pale yellow solid was separated by suction filtration, washed with a mixture of $\mathrm{CH}_{2} \mathrm{Cl}_{2}-n$-hexane 1:5 v/v, and dried in vacuo. Stable colourless crystals of 1 were obtained upon dissolution of the crude material in anhydrous $\mathrm{CHCl}_{3}-\mathrm{MeOH}(4: 1 \mathrm{v} / \mathrm{v})$ and subsequent slow evaporation of the solvents; the crystals were washed with $n$ hexane and dried in vacuo. Yield $0.076 \mathrm{~g}, 0.092 \mathrm{mmol}, 38.9 \%$ based on $\mathrm{Hg}(0)$. Anal. Calcd for $\mathrm{C}_{15} \mathrm{H}_{24} \mathrm{HgI}_{2} \mathrm{~N}_{4} \mathrm{O}_{3} \mathrm{~S}_{2}$ : C 21.79; $\mathrm{H}$ 2.93; N 6.78; S 7.75. Found: C 21.8; H 3.1; N 6.8; S 7.9. Mp
$142-143{ }^{\circ} \mathrm{C} . \delta_{\mathrm{H}}\left(300 \mathrm{MHz} ; \mathrm{CDCl}_{3} / \mathrm{CD}_{3} \mathrm{OD} 4: 1 \mathrm{v} / \mathrm{v}, \mathrm{Me}_{4} \mathrm{Si}\right) 5.63$ $(\mathrm{s}, 1 \mathrm{H} ; \mathrm{C} 5 \mathrm{H}), 2.22\left(\mathrm{t}, 2 \mathrm{H} ; \mathrm{C} \mathrm{H}_{2}\right), 1.50\left(\mathrm{~m}, 2 \mathrm{H}, \mathrm{C} 8 \mathrm{H}_{2}\right), 0.89(\mathrm{t}$, $\left.3 \mathrm{H} ; \mathrm{C} 9 \mathrm{H}_{3}\right) ; \delta_{\mathrm{C}}\left(75.4 \mathrm{MHz}, \mathrm{CDCl}_{3} / \mathrm{CD}_{3} \mathrm{OD} 4: 1 \mathrm{v} / \mathrm{v}, \mathrm{Me}_{4} \mathrm{Si}\right) 174.9$ (CS), 161.7 (CO), 157.2 (C6), 104.6 (C5), 34.0 (C7), 20.4 (C8), 12.8 (C9). FTIR (KBr): $v_{\max } / \mathrm{cm}^{-1} 3458 \mathrm{br}, 2951 \mathrm{w}, 2867 \mathrm{w}, 1652 \mathrm{vs}$, $1634 \mathrm{vs}, 1557 \mathrm{~s}, 1450 \mathrm{~s}, 1401 \mathrm{~m}, 1238 \mathrm{~m}, 1299 \mathrm{~m}, 1170 \mathrm{~s}, 1160 \mathrm{~s}$, $883 \mathrm{w}, 842 \mathrm{~m}, 835 \mathrm{~m}, 775 \mathrm{~m}, 583 \mathrm{~m}, 565 \mathrm{~m}, 522 \mathrm{w}, 450 \mathrm{~m}$.

\section{Synthesis of $\left[\mathrm{HgI}_{2}(\mathrm{PTU})_{2} \cdot \mathrm{HgI}_{2}\right](2)$}

A mixture of PTU-I ${ }_{2}(0.100 \mathrm{~g}, 0.236 \mathrm{mmol})$ and liquid mercury $(0.047 \mathrm{~g}, 0.236 \mathrm{mmol})$ in $80 \mathrm{~mL}$ of $\mathrm{CH}_{2} \mathrm{Cl}_{2}$ was stirred at room temperature for two days. The resulting air-stable pale yellow solid was separated by suction filtration, washed with a mixture of $\mathrm{CH}_{2} \mathrm{Cl}_{2}-n$-hexane $1: 5 \mathrm{v} / \mathrm{v}$, and dried in vacuo. Stable crystals of 2 were obtained upon dissolution of the crude material in anhydrous $\mathrm{CHCl}_{3}$ and subsequent slow evaporation of the solvent; the crystals were washed with $n$-hexane and dried in vacuo. Yield $0.109 \mathrm{~g}, 0.087 \mathrm{mmol}, 0.174 \mathrm{~mol} \mathrm{Hg}(\mathrm{II}), 74 \%$ based on $\mathrm{Hg}(0)$. Anal. Calcd for $\mathrm{C}_{14} \mathrm{H}_{20} \mathrm{Hg}_{2} \mathrm{I}_{4} \mathrm{~N}_{4} \mathrm{O}_{2} \mathrm{~S}_{2}$ : C 13.46; $\mathrm{H} 1.61 ; \mathrm{N}$ 4.48; S 5.13. Found C 13.6; H 1.6; N 4.9; S 5.2. Mp $148-149{ }^{\circ} \mathrm{C} . \delta_{\mathrm{H}}(300 \mathrm{MHz}$; $\left.\mathrm{CDCl}_{3} / \mathrm{CD}_{3} \mathrm{OD} 4: 1 \mathrm{v} / \mathrm{v}, \mathrm{Me}_{4} \mathrm{Si}\right) 5.60(\mathrm{~s}, 1 \mathrm{H} ; \mathrm{C} 5 \mathrm{H}), 2.23(\mathrm{t}, 2 \mathrm{H}$; $\left.\mathrm{C}^{2} \mathrm{H}_{2}\right), 1.49\left(\mathrm{~m}, 2 \mathrm{H}, \mathrm{C} 8 \mathrm{H}_{2}\right), 0.89\left(\mathrm{t}, 3 \mathrm{H} ; \mathrm{C} \mathrm{H}_{3}\right) ; \delta_{\mathrm{C}}(75.4 \mathrm{MHz}$, $\mathrm{CDCl}_{3} / \mathrm{CD}_{3} \mathrm{OD} 4: 1 \mathrm{v} / \mathrm{v}, \mathrm{Me}_{4} \mathrm{Si}$ ) 173.8 (CS), 160.7 (CO), 157.0 (C6), 105.3 (C5), 33.8, (C7), 20.0 (C8), 12.3 (C9); FTIR (KBr): $v_{\max } / \mathrm{cm}^{-1} 3091 \mathrm{w}, 2962 \mathrm{w}, 2928 \mathrm{w}, 1656 \mathrm{vs}, 1618 \mathrm{vs}, 1549 \mathrm{vs}, 1445 \mathrm{~s}$, $1407 \mathrm{~m}, 1338 \mathrm{w}, 1274 \mathrm{w}, 1237 \mathrm{~m}, 1180 \mathrm{vs}, 1163 \mathrm{vs}, 1103 \mathrm{w}, 964 \mathrm{w}$, $882 \mathrm{w}, 838 \mathrm{~m}, 784 \mathrm{w}, 740 \mathrm{w}, 557 \mathrm{~s}, 455 \mathrm{~m}$.

\section{Synthesis of $\left[\mathrm{Hg}_{2} \mathrm{I}_{4}(\mathrm{MeImSH})_{2}\right](3)$}

A mixture of $\mathrm{MeImSH}_{-} \mathrm{I}_{2}(0.139 \mathrm{~g}, 0.270 \mathrm{mmol})$ and liquid mercury $(0.054 \mathrm{~g}, 0.270 \mathrm{mmol})$ in $60 \mathrm{~mL}$ of $\mathrm{CH}_{2} \mathrm{Cl}_{2}$ was stirred at room temperature for two days. The resulting air-stable pale yellow solid was isolated by suction filtration and washed with a mixture of $\mathrm{CH}_{2} \mathrm{Cl}_{2}-n$-hexane $1: 5 \mathrm{v} / \mathrm{v}$, and dried in vacuo. The filtered solution was slowly concentrated to separate further solid. Yield $0.129 \mathrm{~g}, 0.113 \mathrm{mmol}, 0.226 \mathrm{mmol} \mathrm{Hg}(\mathrm{II}), 84 \%$ based on $\mathrm{Hg}(0)$. Anal. Calcd for $\mathrm{C}_{8} \mathrm{H}_{12} \mathrm{Hg}_{2} \mathrm{I}_{4} \mathrm{~N}_{4} \mathrm{~S}_{2}$ : C 8.6; H 1.1; N 5.0; S 5.7. Found: $\mathrm{C} 8.45 ; \mathrm{H} 1.06 ; \mathrm{N} 4.93$; 5.64. $\mathrm{Mp} 134-136{ }^{\circ} \mathrm{C} . \delta_{\mathrm{H}}$ (300 MHz; $\left.\mathrm{CDCl}_{3} / \mathrm{CD}_{3} \mathrm{OD} 4: 1 \mathrm{v} / \mathrm{v}, \mathrm{Me}_{4} \mathrm{Si}\right) 6.59$ (d, 1H, CH), $6.54(\mathrm{~d}, 1 \mathrm{H}, \mathrm{CH}) ; \delta_{\mathrm{C}}\left(75.4 \mathrm{MHz}, \mathrm{CDCl}_{3} / \mathrm{CD}_{3} \mathrm{OD} 4: 1 \mathrm{v} / \mathrm{v}, \mathrm{Me}_{4} \mathrm{Si}\right)$ 154.1 (CS), 118.0 (C4), 122.9 (C5), 36.1 (NMe). FTIR (KBr): $v_{\max } / \mathrm{cm}^{-1} 3108 \mathrm{w}, 1801 \mathrm{w}, 1793 \mathrm{w}, 1770 \mathrm{w}, 1751 \mathrm{w}, 1735 \mathrm{~m}, 1717 \mathrm{~m}$, 1698 s, 1685 m, 1672w, 1653 s, 1635 s, 1616w, 1561 s, 1540 m, 1521 m, $1508 \mathrm{~m}, 1473 \mathrm{~m}, 1458 \mathrm{~m}, 1436 \mathrm{w}, 1418 \mathrm{w}, 1383 \mathrm{w}, 1362 \mathrm{w}, 1288$ m, 1252 m, 1159w, 1100 m, 918w, 852w, 743 m, 667m.

\section{X-ray crystallography}

A summary of the crystal data and refinement details for complexes $\mathbf{1 - 3}$ is given in Table 1 . Intensity data were collected at room temperature for complexes 1-3 on a Bruker Apex II CCD diffractometer using graphite-monochromatized Mo-K $\alpha$ radiation $(\lambda=0.71073 \AA)$. Datasets were corrected for Lorentzpolarization effects and for absorption $\left(S A D A B S^{20}\right)$. All structures were solved by direct methods $\left(S I R-97^{21}\right)$ and completed by iterative cycles of full-matrix least squares refinement on $F_{\mathrm{o}}{ }^{2}$ and $\Delta F$ synthesis using the SHELXL-9722 program (WinGX suite $)^{23}$ Hydrogen atoms, located on the $\Delta F$ maps, with the 
exception of those of the clathrated methanol molecule in complex 1, were allowed to ride on their carbon and nitrogen atoms. Crystallographic data for compounds 1-3 (excluding structure factors) have been deposited with the Cambridge Crystallographic Data Center as supplementary publication no. CCDC-773676, 773945, and 773946, respectively. $\uparrow$ These data can be obtained free of charge via www.ccdc.cam.ac.uk/conts/retrieving.html (or from CCDC, 12 Union Road, Cambridge CB2 1EZ, UK; fax: +44 1223 336033; e-mail: deposit@ccdc.cam.ac.uk.

\section{Computational Studies}

Quantum chemical calculations were carried out on MeImSH$\mathrm{I}_{2}$, PTU- $\mathrm{I}_{2}$, and on the model cations (MeImSH-I) ${ }^{+}$and (PTUI $)^{+}$by means of the commercially available suite of programs Gaussian $03 .{ }^{24}$ Based on the encouraging results reported recently on related diiodine adducts, ${ }^{25}$ density functional calculations (DFT) were performed using the hybrid mPW1PW functional. ${ }^{26}$ For all calculations, Schafer, Horn and Ahlrichs $\mathrm{pVDZ}^{27}$ basis sets (BS's) were used for $\mathrm{C}, \mathrm{H}, \mathrm{N}, \mathrm{O}$, and $\mathrm{S}$ while the recently reported completely uncontracted LANL08 $\mathrm{BS}^{28}$ supplemented with d-polarization functions together with effective core potentials (ECP) was adopted for iodine. Numerical integration was performed using the FineGrid option, which indicates that a total of 7500 points were used for each atom. NBO calculations ${ }^{16}$ were performed for each molecule. Kohn-Sham orbital drawings were elaborated with Molden 4.7. ${ }^{29}$ All calculations were performed on an E4 workstation equipped with four AMD Opteron quad-core processors and $16 \mathrm{~Gb}$ of RAM.

\section{References}

1 (a) Agency for Toxic Substances and Disease Registry (ATSDR). 1999. Toxicological profile for Mercury. Atlanta, GA: U.S. Department, of Health and Human Services, Public Health Service; (b) ATSDR, ToxProfiles: Mercury, U.S. Department, of Health and Human Services, Atlanta, GA, 2005.

2 J. P. K. Rooney, Toxicology, 2007, 234, 145-156, and references cited therein.

3 C. D. Klaassen, Goodman \& Gilman's the Pharmacological Basis of Therapeutics, 11/ed, Chapter 65 (Eds: L. L. Brunton, J. S. Lazo, K. L. Parker), The McGraw-Hill Companies, Inc. USA, 2006, pp. $1753-1776$

4 The interaction between $S$-donor Lewis base (DS) and $\mathrm{I}_{2}$ to give $1: 1$ adducts containing an almost linear $\mathrm{S}-\mathrm{I}-\mathrm{I}$ fragment can be seen as a charge-transfer process. It occurs via the transfer of charge density from a lone pair of electrons $(n)$ on the donor atom to the empty $\sigma^{*}$ antibonding orbital of the iodine species. Depending on the charge density transferred by the DS donor molecule and solvent nature, this can result in lengthening of the I-I bond length up to breaking of the bond. W. T. Pennington, T. W. Hanks, H. D. Arman, Halogen Bonding: Fundamentals and Applications, (Eds: P. Metrangolo and G. Resnati) Spinger-Verlag, Berlin 2008, pp. 65-104, and references therein.

5 V. Lippolis, F. Isaia, Handbook of Chalcogen Chemistry, Chapter 8.2, (Ed. F. A. Devillanova), RCS Publishing: Cambridge, U. K 2007; pp. 477-496.

6 (a) M. C. Aragoni, M. Arca, M. B. Carrea, F. Demartin, F. A. Devillanova, A. Garau, F. Isaia, V. Lippolis and G. Verani, Eur. J. Inorg. Chem., 2004, 23, 4660-4668; (b) F. Bigoli, M. C. Cabras, P. Deplano, M. L. Mercuri, L. Marchiò, A. Serpe and E. F. Trogu, Eur. J. Inorg. Chem., 2004, 5, 960-963.

7 P. D. Cookson and E. R. T. Tiekink, J. Crystallogr. Spectrosc. Res., 1993, 23, 231-234.

8 P. D. Cookson and E. R. T. Tiekink, Z. Kristallogr., 1994, 209, 749-751.

9 Notwithstanding the hydrogen atoms of the methanol were not included in the refinement, the orientation of the molecule and the distance of $3.61 \AA$ A between the $\mathrm{O}$ and the $\mathrm{I} 2$ atoms are congruent with the presence of a hydrogen bond.

10 (a) M. C. Etter, Acc. Chem. Res., 1990, 23, 120-126; (b) M. C. Etter, J. Phys. Chem., 1991, 95, 4601-4610.

11 The presence of $\mathrm{HgI}_{2}$ molecules trapped in an organometallic framework has already been observed only in the $[\mathrm{Cu}(2-$ pyrazinecarboxylato $\left.{ }_{2} \mathrm{HgI}_{2}\right] \cdot \mathrm{HgI}_{2}$ salt-inclusion compound. Y.-B Dong, M. D. Smith and H.-C. zur Loye, Angew. Chem. Int. Ed., 2000, 39, 4271-4273.

12 See for example: (a) E. S. Raper, J. R. Creighton, N. A. Bell, W. Clegg, J. R. Creighton and L. Cucurull-Sanchez, Inorg. Chim. Acta, 1998, 277, 14-20; (b) N. A. Bell, T. N. Branston, W. Clegg, L. Parkera, E. S. Raperc, C. Sammond and C. P. Constabled, Inorg. Chim. Acta, 2001, 319, 130-136; (c) Z. Popović, G. Pavlović, Z. Soldin, J. Popović, D. Matković-Calogović and M. Rajić, Struct. Chem., 2002, 13, 415-424.

13 F. Isaia, M. C. Aragoni, M. Arca, F. Demartin, F. A. Devillanova, G. Floris, A. Garau, M. B. Hursthouse, V. Lippolis, R. Medda, F. Oppo, M. Pira and G. Verani, J. Med. Chem., 2008, 51, 4050-4053.

14 C. T. Antoniadis, G. J. Corban, S. K. Hadjikakou, N. Hadjiliadis, M. Kubicki, S. Warner and I. S. Butler, Eur. J. Inorg. Chem., 2003, 8, $1635-1640$.

15 The interaction strength of $\mathrm{I}_{2}$ with different $S$-based donors (Lewis bases) span a very wide range; on the ground of the $d(\mathrm{~S}-\mathrm{I})$ and $d(\mathrm{I}-\mathrm{I})$ bond lengths recorded for a large number of structurally characterized $1: 1 \mathrm{I}_{2}$-adducts, it is possible to classify the adducts into three categories: (i) weak adducts, $d(\mathrm{I}-\mathrm{I})<2.86 \AA$, where the iodine molecule, is only slightly perturbed/lengthened by the donor molecule interaction; (ii) strong adducts, where the molecular entity I-I can still be recognized and featuring $2.86 \AA<d(\mathrm{I}-\mathrm{I})<3.01 \AA$; (iii) very strong adducts, where the $d(\mathrm{I}-\mathrm{I})>3.01 \AA$. See Reference 5 .

16 (a) A. E. Reed and F. Weinhold, J. Chem. Phys., 1983, 78, 4066-4073; (b) A. E. Reed, R. B. Weinstock and F. Weinhold, J. Chem. Phys., 1985, 83, 735-746; (c) A. E. Reed, L. A. Curtiss and F. Weinhold, Chem. Rev., $1988, \mathbf{8 8}, 899-926$.

17 K. Wiberg, Tetrahedron, 1968, 24, 1083-1096.

18 R. H. Crabtree, Oxidative Addition and Reductive Elimination The Organometallic Chemistry of the Transition Metals; Fourth Edition; Wiley-Interscience: Hoboken, USA 2005; pp 159-182.

19 G. Roy and G. Mugesh, J. Am. Chem. Soc., 2005, 127, 1520715217.

20 G. M. Sheldrick, SADABS Area-Detector Absorption Correction Program, Bruker AXS Inc. Madison, WI, USA, 2000.

21 A. Altomare, M. C. Burla, M. Camalli, G. L. Cascarano, C. Giacovazzo, A. Guagliardi, A. Moliterni, G. Polidori and R. Spagna, J. Appl. Crystallogr., 1999, 32, 115-119.

22 G. M. Sheldrick, Acta Crystallogr., Sect. A: Found. Crystallogr., 2008, A64, 112-122.

23 L. J. Farrugia, J. Appl. Crystallogr., 1999, 32, 837-838.

24 M. J. Frisch, G. W. Trucks, H. B. Schlegel, G. E. Scuseria, M. A. Robb, J. R. Cheeseman, J. A. Montgomery Jr., T. Vreven, K. N. Kudin, J. C. Burant, J. M. Millam, S. S. Iyengar, J. Tomasi, V. Barone, B. Mennucci, M. Cossi, G. Scalmani, N. Rega, G. A. Petersson, H. Nakatsuji, M. Hada, M. Ehara, K. Toyota, R. Fukuda, J. Hasegawa, M. Ishida, T. Nakajima, Y. Honda, O. Kitao, H. Nakai, M. Klene, X. Li, J. E. Knox, H. P. Hratchian, J. B. Cross, V. Bakken, C. Adamo, J. Jaramillo, R. Gomperts, R. E. Stratmann, O. Yazyev, A. J. Austin, R. Cammi, C. Pomelli, J. W. Ochterski, P. Y. Ayala, K. Morokuma, G. A. Voth, P. Salvador, J. J. Dannenberg, V. G. Zakrzewski, S. Dapprich, A. D. Daniels, M. C. Strain, O. Farkas, D. K. Malick, A. D. Rabuck, K. Raghavachari, J. B. Foresman, J. V. Ortiz, Q. Cui, A. G. Baboul, S. Clifford, J. Cioslowski, B. B. Stefanov, G. Liu, A. Liashenko, P. Piskorz, I. Komaromi, R. L. Martin, D. J. Fox, T. Keith, M. A. Al-Laham, C. Y. Peng, A. Nanayakkara, M. Challacombe, P. M. W. Gill, B. Johnson, W. Chen, M. W. Wong, C. Gonzalez, and J. A. Pople, Gaussian 03, Gaussian, Inc., Wallingford CT, 2004.

25 F. Isaia, M. C. Aragoni, M. Arca, F. Demartin, F. A. Devillanova, G. Ennas, A. Garau, V. Lippolis, A. Mancini and G. Verani, Eur. J. Inorg. Chem., 2009, 3667-3672.

26 C. Adamo and V. Barone, J. Chem. Phys., 1998, 108, 664-675.

27 A. Schäfer, H. Horn and R. Ahlrichs, J. Chem. Phys., 1992, 97, 25712576.

28 L. E. Roy, P. J. Hay and R. L. Martin, J. Chem. Theory Comput., 2008, 4, 1029-1031.

29 G. Schaftenaar and J. H. Noordik, J. Comput.-Aided Mol. Des., 2000, 14, 123-134. 